\author{
Kinga Krzesiwo \\ Kamila Ziółkowska-Weiss \\ Michał Żemła \\ Uniwersytet Pedagogiczny w Krakowie \\ Wydział Geograficzno-Biologiczny \\ Instytut Geografii \\ krzesiwo@up.krakow.pl \\ kamilacamela@up.krakow.pl \\ michalzemla@up.krakow.pl
}

\title{
ATRAKCYJNOŚĆ WYBRANYCH PAŃSTW EUROPY ŚRODKOWEJ POD KĄTEM UPRAWIANIA SPORTÓW ZIMOWYCH I PIESZEJ TURYSTYKI GÓRSKIEJ
}

\begin{abstract}
Abstrakt: Celem autorów artykułu jest próba dokonania oceny atrakcyjności wybranych państw Europy Środkowej pod kątem uprawiania sportów zimowych i pieszej turystyki górskiej w świetle opinii studentów kierunków związanych z turystyką, mieszkających w państwach Grupy Wyszehradzkiej, oraz ocena barier rozwoju konkurencyjnej oferty w tych krajach. Według respondentów najbardziej atrakcyjnymi krajami do uprawiania sportów zimowych są Austria i Słowacja, a najmniej - Węgry, Rumunia i Litwa. Z kolei najlepsze warunki do uprawiania pieszej turystyki górskiej, według ankietowanych, mają Słowacja, Austria i Czechy oraz Polska. Ponadto badani z poszczególnych państw wysoko ocenili ofertę krajową.
\end{abstract}

Słowa kluczowe: atrakcyjność turystyczna, sporty zimowe, piesza turystyka górska, Europa Środkowa.

\section{WSTĘP}

Rekreacja może być rozumiana jako zespół działań i zachowań podejmowanych przez jednostkę w czasie wolnym. Powszechnie przyjęty jest podział rekreacji na czynną i bierną (LUBOWIECKI-VIKUK, PACZYŃSKA-JĘDRYCKA 2010). Stosuje się również rozróżnienie na rekreację ruchową (fizyczną), rekreację twórczą, kulturalno-rozrywkową, ale także określona działalność społeczna bywa traktowana jako forma rekreacji (KIEEBASIEWICZ-DROZDOWSKA 2001, s. 16). Warto zauważyć, że w wymienionych podziałach na pierwszy plan wysuwają się różnego rodzaju formy rekreacji związane z aktywnością ruchową, określane jako rekreacja ruchowa, rekreacja fizyczna, czy też sport dla wszystkich (WOLAŃSKA 1997) - wzajemne relacje tych pojęć omawiają m.in. D. DUDEK (2006) oraz A.P. LUBOWIECKI-VIKUK, M. PACZYŃSKA-JĘDRYCKA (2010). Rekreacja ruchowa obejmuje wiele różnych form aktywności, takich jak: jazda na rowerze, jazda na nartach, piesze wycieczki, sporty wodne czy taniec. Pojęciem blisko związanym z rekreacją ruchową jest "turystyka aktywna", rozumiana jako forma turystyki, w której głównym lub ważnym elementem wyjazdu jest - niezależnie od czasu jego trwania - podejmowanie szczególnego rodzaju aktywności rekreacyjnej lub hobbystycznej (ANDREJUK 1998)1. Obejmuje ona zarówno tradycyjne formy, np. turystykę pieszą, rowerową, kajakową, jak i nowsze - canyoning czy geocaching. Warto zauważyć, że większość wymienionych form rekreacji ruchowej i turystyki aktywnej uprawiana jest przede wszystkim w plenerze. Może być podejmowana $\mathrm{w}$ czasie wolnym $\mathrm{w}$ domu, ale też $\mathrm{w}$ ramach wyjazdów turystycznych. Co więcej, część z tych form aktywności wymaga tego, aby uprawiane były w określonym środowisku przyrodniczym. Dotyczy to zwłaszcza wycieczek pieszych i narciarstwa, kojarzonych przede wszystkim $z$ terenami górskimi, oraz sportów wodnych, powiązanych z naturalnymi bądź sztucznymi akwenami lub ciekami. Piesza turystyka górska oraz sporty zimowe, głównie narciarstwo zjazdowe i snowboarding, należą do najpopularniejszych form turystyki aktywnej, dlatego nie negując znaczenia i popularności pozostałych form turystyki aktywnej, 
uprawianych na terenach górskich, w niniejszym artykule autorzy ograniczyli analizę do tych dwóch form turystyki. Ich popularność i masowa skala uprawiania wynikają nie tylko $\mathrm{z}$ występowania odpowiednich walorów przyrodniczych, ale także, a w przypadku sportów zimowych przede wszystkim, z właściwego zagospodarowania tych miejsc. Dla podmiotów gospodarczych, prowadzących działalność związaną z obsługą osób uprawiających turystykę pieszą i/lub sporty zimowe, stanowią one rynek docelowy, do którego kierują swoją ofertę, przygotowywaną tak, by była w stanie przyciągnać jak najwięcej klientów. Z kolei efektywność działań podażowych sprawia, że po stronie popytu pojawia się coraz szerszy zakres możliwości wyboru oraz wzrastają oczekiwania co do jakości oferowanego produktu. Tym samym rynek staje się bardziej konkurencyjny, a konkurencja pomiędzy firmami oraz miejscami przyciągającymi turystów pieszych i/lub uprawiających sporty zimowe nabiera charakteru już nie tylko lokalnego czy regionalnego, ale także krajowego, a nawet międzynarodowego.

\section{CEL I METODYKA BADAŃ}

Celem autorów artykułu jest próba dokonania oceny atrakcyjności wybranych państw Europy Środkowej pod kątem możliwości uprawiania sportów zimowych i pieszej turystyki górskiej, w świetle opinii studentów kierunków związanych z turystyką, mieszkających w państwach Grupy Wyszehradzkiej, oraz ocena barier rozwoju konkurencyjnej oferty $\mathrm{w}$ tych krajach.

Aby móc zrealizować tak postawiony cel dokonano krytycznej analizy literatury, co pozwoliło na identyfikację głównych barier rozwojowych pieszej turystyki górskiej i sportów zimowych w Polsce, Republice Czeskiej i Słowacji, oraz przeprowadzono badania ankietowe. Kwestionariusz ankiety umieszczono w Internecie w pierwszej połowie 2016 r. Skierowano go do studentów kierunków związanych z turystyką w krajach należących do Grupy Wyszehradzkiej. W ankiecie wzięło udział 195 osób, w tym 78 ze Słowacji, 46 z Republiki Czeskiej, 43 z Polski i 28 z Węgier. Badania odbywały się na drodze współpracy między wykładowcami różnych uczelni w tych krajach. Udostępniali oni studentom link do kwestionariusza, który następnie był upowszechniany metodą tzw. śnieżnej kuli.

Przedmiotem oceny respondentów była atrakcyjność oferty dziewięciu krajów Europy Środkowej: Austrii, Litwy, Niemiec, Polski, Republiki Czeskiej, Rumunii, Słowacji, Słowenii i Węgier², pod kątem uprawiania sportów zimowych oraz pieszej turystyki górskiej. Ankietowani byli proszeni o wskazanie najwyżej pięciu krajów, które ich zdaniem są najbardziej atrakcyjne pod względem uprawiania w nich wymienionych form turystyki aktywnej.

\section{WYBRANE WSPÓŁCZESNE KIERUNKI I BARIERY ROZWOJU OŚRODKÓW SPORTÓW ZIMOWYCH I OŚRODKÓW PIESZEJ TURYSTYKI GÓRSKIEJ W POLSCE}

Rozwój zagospodarowania terenu do uprawiania sportów zimowych ${ }^{3}$ jest ważnym czynnikiem rozwoju ekonomicznego, wzrostu demograficznego oraz źródłem zatrudnienia i dochodów miejscowych społeczności. Przyczynia się ono również do poprawy jakości infrastruktury społeczno-technicznej w miejscowościach górskich (KUREK 2004, LINDBERG i in. 2001). Jednakże poza korzyściami gospodarczymi i społecznymi rozwój bazy dla tej formy aktywności powoduje wiele niekorzystnych skutków przyrodniczych, będących efektem budowy infrastruktury turystycznej, szczególnie narciarskiej, oraz przebywania na stosunkowo niewielkim terenie dużej liczby osób (HOLDEN 2000, HUDSON 2000, KUREK 2004, TSUYUZAKI 2002). W badaniach naukowych często podejmuje się też temat wpływu zmian klimatycznych na funkcjonowanie ośrodków sportów zimowych (TÖGLHOFER 2011, FALK 2010) oraz zagadnienie sezonowości (HERBIN 1995, TUPPEN 2002) i spowolnienia popytu na najważniejszych dojrzałych rynkach europejskich (TUPPEN 2002, HUDSON, HUDSON 2015).

Znacznie mniej uwagi w pracach badawczych poświęcono w ostatnich latach tematyce pieszej turystyki górskiej. W tym przypadku naukowcy koncentrują się najczęściej na wpływie tej aktywności na środowisko przyrodnicze (GENELETTI, DAWA 2009, FIDELUS 2016, FIDELUS-ORZECHOWSKA i in. 2017), rzadziej uwzględniają aspekty ekonomiczne $\mathrm{i} /$ lub organizacyjne (ZARZYCKI i in. 2006, SZCZECHOWICZ 2006, ŻEMŁA 2015).

Wzrost liczby osób uprawiających narciarstwo lub snowboarding, zwiększenie częstotliwości wyjazdów turystycznych oraz wyraźny wzrost wymagań Polaków co do jakości świadczonych usług prowadzi do niespotykanego dotąd boomu inwestycyjnego w polskich ośrodkach narciarskich, jaki obserwowany jest od początku XXI w. W tym okresie liczba nowoczesnych i wygodnych kolei linowych w polskich ośrodkach uległa zwielokrotnieniu. Tradycyjne ośrodki narciarskie są sukcesywnie modernizowane, powstają też ośrodki nowe, zarówno małe, typowo rodzinne, jak i duże, oferujące bardziej zróżnicowane trasy. O poprawie jakości usług polskich ośrodków narciarskich świadczy też fakt, że zdecydowana większość tras zjazdowych została wyposażona w systemy naśnieżania, 
a wiele $\mathrm{z}$ nich także oświetlono. Zwiększanie się ruchu turystycznego $\mathrm{w}$ polskich stacjach narciarskich oraz dynamiczny rozwój ośrodków narciarskich stwarza także wiele sytuacji konfliktowych, będących źródłem barier rozwoju i funkcjonowania ośrodków oraz stacji narciarskich. W polskiej literaturze naukowej zagadnienie to było podejmowane m.in. przez K. KRZESIWO (2007, 2014), M. MIKĘ (2009), M. MIKĘ i in. (2007).

Z badań przeprowadzonych przez K. KRZESIWO (2014) wśród osób zarządzających ośrodkami narciarskimi wynika, że najistotniejszym problemem dla gestorów bazy narciarskiej w Polsce jest aspekt prawny związany z ochroną środowiska. Prawo dotyczące ochrony środowiska powoduje bowiem, że proces proceduralno-administracyjny jest niezmiernie skomplikowany i uciążliwy dla inwestorów. Kolejną istotną kwestią jest brak regulacji prawnych porządkujących relacje między właścicielami gruntów a gestorami baz narciarskich. Efektem braku zgody co do finansowych warunków dzierżawy gruntów jest wyłączenie z działalności wyciągów i tras narciarskich. Konflikty te są najbardziej odczuwalne $\mathrm{w}$ tradycyjnych stacjach narciarskich, takich jak: Piwniczna-Zdrój, Szczyrk, Zakopane czy Zwardoń.

W związku z postępującymi zmianami klimatu, powodującymi niepewność śniegową oraz niestabilność warunków pogodowych, ośrodki narciarskie są zmuszone dostosować się do nowych realiów. Najpopularniejszą strategią adaptacyjną do zmian klimatycznych jest stosowanie urządzeń do produkcji śniegu. Naśnieżanie wymaga dostarczenia dużej ilości wody, jednak nie każdy ośrodek narciarski ma swobodny dostęp do jej naturalnych zasobów. Jednym z najistotniejszych problemów związanych z rozwojem i funkcjonowania ośrodków narciarskich w Polsce jest więc niedostępność odpowiedniej ilości wody, niezbędnej do naśnieżania stoków. Intensywne naśnieżanie stoków istotnie wpływa także na rentowność poszczególnych ośrodków.

Jednym z ważniejszych elementów atrakcyjności turystycznej jest możliwość szybkiego i wygodnego dojazdu do miejsca docelowego oraz sprawność systemu komunikacji wewnętrznej. Dotkliwymi wadami tego systemu w niektórych stacjach narciarskich są częste zatory drogowe, zbyt wąskie i złej jakości drogi dojazdowe do ośrodków narciarskich, niewystarczająca liczba miejsc parkingowych oraz niesprawnie funkcjonujący system odśnieżania.

Istotnym aspektem jest także zacieśniana w ostatnich latach współpraca pomiędzy gestorami ośrodków narciarskich, która w państwach ościennych (Republika Czeska, Słowacja) funkcjonuje od dawna i dzięki której w krajach tych od lat działają efektywne systemy kategoryzacji branżowej oraz wydajne systemy informacji w Internecie.
Inaczej niż w przypadku sportów zimowych, liczba osób uprawiających pieszą turystykę górską w ostatnich latach nie zmienia się znacząco (PILAWSKI 2002, ŻEMŁA 2015). Nie przybywa również oznakowanych szlaków turystycznych oraz schronisk, będących ważnym elementem zagospodarowania turystycznego terenów górskich. Fakt ten, a także specyfika tej aktywności, niewymagającej do obsługi skomplikowanej infrastruktury technicznej, sprawia, że w niniejszym przypadku trudno wskazać istotne inwestycje w tym zakresie w ostatnich latach. Warto jednak podkreślić, że większość kolei linowych, budowanych z myślą o obsłudze turystów w zimie, także w sezonie letnim jest udostępniana turystom pieszym, a nieraz również uprawiającym kolarstwo górskie, co znacznie poprawia dostępność wielu atrakcyjnych terenów górskich.

\section{WYBRANE BARIERY ROZWOJU OŚRODKÓW SPORTÓW ZIMOWYCH I PIESZEJ TURYSTYKI GÓRSKIEJ NA SŁOWACJI I W REPUBLICE CZESKIEJ}

W Republice Czeskiej i na Słowacji branża sportów zimowych, w porównaniu z Polską, jest dojrzała i obecnie wymaga, by o nią ciągle dbano w celu utrzymywania wysokiego poziomu popytu. Według A. MADZIKOVEJ i in. (2011) do najważniejszych barier rozwoju i funkcjonowania ośrodków narciarskich na Słowacji należą:

- kwestie prawne wynikające z ochrony przyrody,

- niedobór środków finansowych na modernizację infrastruktury narciarskiej,

- brak zasad prawnych regulujących sposób i zakres udostępniania gruntów na cele narciarskie pomiędzy właścicielami gruntów a zarządzającymi ośrodkami narciarskimi,

- spadek zainteresowania uprawianiem narciarstwa na Słowacji ze strony turystów zagranicznych.

Realizacja dużych projektów inwestycyjnych związanych z rozwojem słowackich ośrodków narciarskich jest $\mathrm{w}$ niektórych przypadkach zagrożona ze względu na ograniczenia prawne związane z ochroną przyrody. Wiele ośrodków narciarskich na Słowacji znajduje się na obszarach objętych międzynarodową siecią Natura 2000 (MADZIKOVA i in. 2011).

Chcąc uwzględniać zmieniające się warunki klimatyczne, a jednocześnie zwiększać atrakcyjność turystyczną, właściciele infrastruktury narciarskiej są zmuszeni do podnoszenia jakości świadczonych usług poprzez budowę systemów naśnieżania tras narciarskich oraz modernizację istniejących urządzeń transportujących narciarzy po stokach. Niektóre ośrodki narciarskie, 
szczególnie te położone przy hotelach górskich, nie mają niestety możliwości finansowych i organizacyjnych, by zrealizować takie inwestycje. Z tego powodu upada coraz więcej małych ośrodków narciarskich na Słowacji.

Na Słowacji oraz w Republice Czeskiej, podobnie jak w Polsce, najpoważniejszym problemem związanym $\mathrm{z}$ rozbudową i funkcjonowaniem ośrodków narciarskich - jak już wcześniej wspomniano - są bariery prawne związane $\mathrm{z}$ polityką ochrony środowiska (HAVRLANT 2011). W wielu przypadkach przedstawiciele organizacji ekologicznych blokują nawet takie przedsięwzięcia, których celem jest poprawa organizacji terenów rekreacyjnych, wcześniej już przekształconych przez człowieka.

$\mathrm{Na}$ terenach górskich w Czechach pojawiają się także problemy statusu własnościowego gruntów. Konflikty te nie mają jednak takiego nasilenia jak w polskiej części Karpat (por. KRZESIWO 2014, MIKA i in. 2007). Spory własnościowe pojawiają się m.in. w trakcie zaplanowanych modernizacji ośrodków narciarskich. $\mathrm{Na}$ skutek nieuregulowanych kwestii własnościowych zatrzymano m.in. proces rozbudowy ośrodka narciarskiego na Jaworowym Wierchu (1013 m n.p.m.).

Interesującą kwestią są istotne różnice w sposobie i kierunkach rozwoju górskiej turystyki pieszej w Republice Czeskiej, na Słowacji i w Polsce (SzCZECHOWICZ 2014, ŻEMŁA 2015). O ile popularność tej formy rekreacji jest w poszczególnych krajach podobna, to w sposobie zagospodarowania obszarów górskich widać istotne różnice. Dotyczy to zarówno sposobu wyznaczania szlaków, jak i funkcjonowania schronisk górskich. Różnice dotyczące szlaków związane są przede wszystkim z podawaniem długości szlaku w kilometrach w Republice Czeskiej oraz godzin marszu w Polsce i na Słowacji. Co do schronisk, to różna jest ich liczba, własność, standard i dostępność. Zdecydowanie mało schronisk zlokalizowanych jest na Słowacji. Są to przeważnie obiekty typowo wysokogórskie, o podstawowym wyposażeniu, bardzo trudno dostępne, których zaopatrzenie odbywa się dzięki tragarzom. Większość schronisk skoncentrowana jest w najbardziej atrakcyjnych pasmach (Tatry, Fatra), podczas gdy na pozostałych obszarach górskich schronisk nie ma wcale. Odmienna sytuacja występuje w Republice Czeskiej, gdzie schronisk jest dużo. Są one względnie równomiernie rozmieszczone. $Z$ reguły są to hotele górskie o wysokim standardzie, do których możliwy jest dojazd samochodem nie tylko w celach zaopatrzeniowych, ale także dla wygody gości hotelowych. Inaczej niż w Polsce i na Słowacji, gdzie większość schronisk prowadzona jest przez stowarzyszenia i kluby turystów (przede wszystkim PTTK i KST), najwięcej obiektów czeskich stanowi własność prywatną. Z kolei w Polsce schroniska górskie są liczne i równomiernie rozmieszczone. Zazwyczaj da się do nich dotrzeć samochodem terenowym w celach zaopatrzeniowych. Ich standard jest podstawowy, a właścicielem większości jest PTTK. Dość charakterystyczne jest to, że mieszkańcy wszystkich trzech krajów uprawiają pieszą turystykę górską jako krajową (ŻEMŁA 2014, 2015).

\section{OCENA ATRAKCYJNOŚCI OFERTY ANALIZOWANYCH PAŃSTW W OPINII STUDENTÓW}

Elementem wpływającym $\mathrm{w}$ znacznym stopniu na obecną i przyszłą pozycję konkurencyjną poszczególnych destynacji jest ich zdolność do przyciągania gości, powiązana z atrakcyjnością turystyczną. Oceny atrakcyjności turystycznej państw Europy Środkowej dokonano, wykorzystując metodę subiektywną, poprzez ankietyzację turystów. Respondenci byli poproszeni o wybranie spośród dziewięciu państw wymienionych $w$ tab. 1 i 2 pięciu najbardziej atrakcyjnych w zakresie uprawiania sportów zimowych oraz turystyki pieszej. Odsetek wskazań ankietowanych co do najatrakcyjniejszych ich zdaniem krajów w zakresie uprawiania sportów zimowych przedstawia tab. 1.

Według ankietowanych zdecydowanie najatrakcyjniejszymi krajami do uprawiania sportów zimowych są Austria i Słowacja (tab. 1). Takiej odpowiedzi udzielili zgodnie respondenci z wszystkich badanych krajów. Na kolejnych miejscach odpowiednio znalazły się Niemcy, Republika Czeska, Słowenia oraz Polska. Najmniejszą liczbę pozytywnych odpowiedzi uzyskały Węgry, Rumunia i Litwa, co oznacza, że kraje te są mniej atrakcyjnymi destynacjami do uprawiania sportów zimowych. Charakterystyczne jest to, że badani z poszczególnych państw wysoko oceniali ofertę krajową. Ponadto na znaczny odsetek odpowiedzi preferujących Republikę Czeską i Słowację może wpływać stosunkowo duża liczba Czechów i Słowaków biorących udział w badaniach. Analizując ankiety respondentów, należy zauważyć, że bliskość geograficzna poszczególnych państw może być ważnym czynnikiem wpływającym na uzyskane wyniki. Uwagę zwraca duża liczba odpowiedzi wskazujących Niemcy wśród ankietowanych z Republiki Czeskiej. Natomiast spośród respondentów z Polski nikt nie wybrał Litwy jako atrakcyjnego kraju, w którym można by uprawiać sporty zimowe. Niewielka liczba Słowaków biorących udział $\mathrm{w}$ ankiecie traktuje $\mathrm{z}$ kolei podobnie Węgry, twierdząc, że ten kraj nie jest atrakcyjny dla miłośników uprawiania sportów zimowych.

Z kolei krajami o najlepszych warunkach do uprawiania pieszej turystyki górskiej, zdaniem badanych, są: Słowacja, Austria oraz Republika Czeska (tab. 2). Na czwartym miejscu znalazła się Polska. Najmniejszą 
Tab. 1. Odsetek wskazań respondentów z Polski, Republiki Czeskiej, Słowacji i Węgier odnośnie do najatrakcyjniejszych ich zdaniem krajów do uprawiania sportów zimowych

\begin{tabular}{|c|c|c|c|c|c|c|c|c|c|}
\hline \multirow[b]{2}{*}{$\begin{array}{l}\text { Narodowość } \\
\text { respondentów }\end{array}$} & \multicolumn{9}{|c|}{ Wskazywane przez respondentów kraje (\%) } \\
\hline & Austria & Litwa & Niemcy & Polska & $\begin{array}{c}\text { Republika } \\
\text { Czeska }\end{array}$ & Rumunia & Słowacja & Słowenia & Węgry \\
\hline Polacy & 95,3 & 0,0 & 41,9 & 79,1 & 53,5 & 9,3 & 88,4 & 55,8 & 11,6 \\
\hline Czesi & 97,8 & 10,9 & 73,9 & 16,6 & 84,8 & 10,9 & 84,8 & 60,9 & 10,9 \\
\hline Słowacy & 94,9 & 11,5 & 59,0 & 52,6 & 50,0 & 9,0 & 92,3 & 44,9 & 2,6 \\
\hline Węgrzy & 92,9 & 21,4 & 57,1 & 50,0 & 39,3 & 10,7 & 64,3 & 50,0 & 10,7 \\
\hline Ogółem & 95,4 & 10,3 & 58,6 & 50,3 & 57,4 & 9,7 & 85,6 & 51,8 & 7,7 \\
\hline
\end{tabular}

Źródło: opracowanie własne.

Tab. 2. Odsetek wskazań respondentów z Polski, Republiki Czeskiej, Słowacji i Węgier odnośnie do najatrakcyjniejszych ich zdaniem krajów w zakresie uprawiania pieszej turystyki górskiej

\begin{tabular}{|l|c|c|c|c|c|c|c|c|c|}
\hline \multirow{2}{*}{$\begin{array}{c}\text { Narodowość } \\
\text { respondentów }\end{array}$} & \multicolumn{7}{|c|}{ Wskazywane przez respondentów kraje (\%) } \\
\cline { 2 - 13 } & Austria & Litwa & Niemcy & Polska & $\begin{array}{c}\text { Republika } \\
\text { Czeska }\end{array}$ & Rumunia & Słowacja & Słowenia & \multirow{2}{*}{ Węgry } \\
\hline Polacy & 67,4 & 9,3 & 34,9 & 88,4 & 58,1 & 39,5 & 74,4 & 53,5 & 25,6 \\
\hline Czesi & 89,1 & 17,4 & 41,3 & 26,1 & 82,6 & 32,6 & 78,3 & 63.0 & 21,7 \\
\hline Słowacy & 73,1 & 12,8 & 43,6 & 60,3 & 60,3 & 37,2 & 93,6 & 50,0 & 19,2 \\
\hline Węgrzy & 67,9 & 14,3 & 60,7 & 32,1 & 35,7 & 53,6 & 46,3 & 32,1 & 50,0 \\
\hline Ogółem & 74,9 & 13,3 & 43,6 & 54,4 & 61,5 & 39,0 & 79,0 & 51,3 & 25,6 \\
\hline
\end{tabular}

Źródło: opracowanie własne.

liczbę wskazań uzyskały odpowiednio Litwa, Węgry oraz Rumunia. Można zauważyć, że Czesi uznali Austrię za kraj ich zdaniem najlepszy do uprawiania turystyki pieszej. Podobnie jak w przypadku poprzedniego pytania respondenci często wskazywali na ofertę krajową. Tak było w odpowiedziach Słowaków, którzy jednoznacznie ocenili, że Słowacja jest najlepszym krajem na letnie górskie wycieczki. Polacy z kolei preferowali Polskę. Zastanawiać może odpowiedź respondentów z Węgier, którzy uważają swój kraj za dobre miejsce do uprawiania turystyki pieszej. Ich entuzjazmu nie podzielają jednak ankietowani $\mathrm{z}$ innych krajów, którzy uznali Węgry i Litwę za kraje najmniej sprzyjające uprawianiu pieszej turystyki górskiej. Rumunia otrzymała najwięcej wskazań od Węgrów, podczas gdy ankietowani z innych krajów ocenili ten kraj znacznie gorzej pod tym względem.

\section{PODSUMOWANIE}

Słowacja jest krajem górzystym. Tereny wzniesione na wysokości od 300 do 800 m n.p.m. zajmują blisko 47\% jej powierzchni, a ponad $800 \mathrm{~m}$ n.p.m. - około 13\%. Z kolei Republika Czeska zaliczana jest do krajów wyżynnych, gdyż obszary położone na wysokościach 300-800 m n.p.m. zajmują aż 72\% powierzchni kraju, a powyżej 800 m n.p.m. - tylko 4\%. Polska należy nato- miast do krajów nizinnych, a tereny położone powyżej $500 \mathrm{~m}$ n.p.m. stanowią zaledwie 3\% jej powierzchni. Pomimo to obszary górskie na Słowacji, w Czechach i w Polsce stanowią największe i najważniejsze regiony turystyczne tych państw (WARSZYŃSKA 1995).

Najbardziej charakterystycznymi formami rekreacji w górach są narciarstwo i turystyka piesza. Na terenach górskich w Polsce, Czechach i na Słowacji dąży się do przygotowywania konkurencyjnej oferty i przyciągania osób uprawiających te formy aktywności. Relatywne podobieństwo uwarunkowań naturalnych oraz społeczno-ekonomicznych powoduje, że te trzy kraje mają podobne możliwości rozwoju oraz borykają się $\mathrm{z}$ analogicznymi trudnościami. Jednak nasilenie niektórych problemów w poszczególnych krajach może być różne. W Polsce ośrodki narciarskie ograniczone są przede wszystkim kwestiami związanymi z własnością gruntów i ochroną przyrody. Wydaje się, że w Republice Czeskiej i na Słowacji większą rolę odgrywa mała liczba mieszkańców kraju połączona z trudnością przystąpienia do konkurencji międzynarodowej, zwłaszcza z Austrią i innymi krajami alpejskimi. Podobnie jak oferta sportów zimowych, także oferta pieszej turystyki górskiej $\mathrm{w}$ trzech analizowanych krajach budowana jest przede wszystkim z myślą o turystach krajowych. Jednak różnice $\mathrm{w}$ oczekiwaniach nabywców na tych trzech rynkach znajdują wyraz także $w$ nieznacznie odmiennej organizacji tej oferty w Polsce, na Słowacji i w Republice Czeskiej. 
$\mathrm{Na}$ podstawie przeprowadzonych analiz można stwierdzić, że perspektywy rozwoju sportów zimowych i pieszej turystyki górskiej we wszystkich badanych krajach $\mathrm{w}$ znacznym stopniu powiązane są $\mathrm{z}$ tendencjami popytu $w$ tych krajach. Potwierdzeniem znaczenia turystyki krajowej $w$ regionach górskich tych państw są także wyniki prezentowanych badań ankietowych. W każdym przypadku oferta $\mathrm{z}$ danego kraju uzyskała zawyżone wyniki wśród pochodzących z niego respondentów. Jednak mocna pozycja Słowacji jako atrakcyjnego miejsca dla pieszej turystyki górskiej i dla sportów zimowych jest bezdyskusyjna. Wśród badanych państw Słowacja ustąpiła miejsca jedynie Austrii w zakresie oferty sportów zimowych. Natomiast Polska i Czechy, w obu rankingach z wynikiem przekraczającym $50 \%$, znalazły się zaraz za najlepszą dwójką państw, jednak w obu przypadkach oceny Republiki Czeskiej były istotnie wyższe niż Polski. Jedną z przyczyn tej sytuacji jest bardzo niska ocena atrakcyjności Polski w obu przypadkach dokonana przez Czechów, podczas gdy Polacy ocenili atrakcyjność Republiki Czeskiej zdecydowanie wyżej. Oprócz Austrii ważnymi konkurentami objętych badaniem państw w Europie Środkowej są także Niemcy, Słowenia i Rumunia; ta ostatnia jednak tylko $\mathrm{w}$ zakresie turystyki pieszej, gdyż jej oferta narciarska została oceniona zaskakująco nisko.

\section{PRZYPISY}

${ }^{1} \mathrm{~W}$ literaturze polskiej często wykorzystuje się trudny do przetłumaczenia na język angielski zwrot ",turystyka kwalifikowana". Szeroką dyskusję o wzajemnym związku pojęć "turystyka kwalifikowana" i "turystyka aktywna” można znaleźć m.in. w pracach A. ANDREJUK (1998), M. ŻEMŁY (2000), J. RUT (2002).

2 Prezentowane wyniki są fragmentem większego badania, w którym analizowano atrakcyjność turystyczną państw Europy Środkowej, nie tylko w odniesieniu do obszarów górskich, stąd w zestawieniu obecność Litwy i Węgier.

${ }^{3} \mathrm{~W}$ literaturze krajowej brakuje jednoznacznej terminologii związanej z uprawianiem narciarstwa, snowboardingu oraz miejscami zagospodarowanymi w tym celu. $\mathrm{W}$ niniejszym artykule posłużono się terminem „ośrodek sportów zimowych" będącym tłumaczeniem popularnego $\mathrm{w}$ literaturze anglojęzycznej zwrotu "winter sport resort/destination" (HUDSON 2000, HUDSON, HUDSON 2015, FLAGESTAD, HOPE 2001, TUPPEN 2002), natomiast pojęcia "stacja" oraz "ośrodek" w odniesieniu do sportów zimowych zostały zastosowane zgodnie $\mathrm{z}$ definicjami zaproponowanymi przez K. KRZESIWO (2014, s. 21).

\section{BIBLIOGRAFIA}

ANDREJUK A., 1998, Turystyka aktywna, rekreacyjna i specjalistycz$n a$, Kengraf, Warszawa.

DUDEK D., 2006, Pojęcie rekreacji w polskiej tradycji terminologicznej, „Folia Touristica”, 17, s. 27-50.

FALK M., 2010, A dynamic panel data analysis of snow depth and winter tourism, „Tourism Management”, 31, 6, s. 912-924.
FIDELUS J., 2016, Slope transformations within tourist foot-paths in the northern and southern parts of the Western Tatra Mountains (Poland, Slovakia), „Zeitschrift für Geomorphologie”, 60 (3), s. $139-162$.

FIDELUS-ORZECHOWSKA J., GORCZYCA E., KRZEMIEŃ K., 2017, Geomorfologiczne skutki gospodarki turystycznej w Tatrach, Wyd. IGiGP UJ, Kraków.

FlAGESTAD A., HOPE C. A., 2001, Strategic success in winter sports destinations: A sustainable value creation perspective, "Tourism Management", 22 (5), s. 445-461.

GENELETTI D., DAWA D., 2009, Environmental impact assessment of mountain tourism in developing regions: A study in Ladakh, Indian Himalaya, "Environmental Impact Assessment Review", 29 (4), s. 229-242.

HAVRLANT J., 2011, Kierunki i bariery modernizacji ośrodków sportów zimowych w czeskim regionie turystycznym 'Beskidy', ,Prace Geograficzne", 125, s. 77-93.

HERBIN J., 1995, Mass tourism and problems of tourism planning in french mountains, [w:] G.J. Alshworth, A.G. Dietvorst (red.), Tourism and spatial transformations, CABI, Wallingford.

HOLDEN A., 2000, Winter tourism and the environment in conflict: the case study of Cairngorm, Scotland, "International Journal of Tourism Research", 2, 4, s. 247-260.

HuDSON S., 2000, Snow business. A study of the International ski industry, Cassell, London.

HUDSON S., HUDSON L., 2015, Winter sport tourism, Goodfellow Publishers, Oxford.

KIEŁBASIEWICZ-DROZDOWSKA I., 2001, Zarys rozwoju refleksji teoretycznej nad problematyka rekreacji, [w:] I. Kiełbasiewicz-Drozdowska, W. Siwiński (red.), Teoria i metodyka rekreacji, AWF, Poznań, s. 9-25.

KRZESIWO K., 2007, Turystyka narciarska w Beskidzie Śląskim - stan obecny i problemy rozwoju, [w:] W. Kurek, R. Faracik (red.), Studia nad turystyka. Prace geograficzne i regionalne. Geograficzne, społeczne i ekonomiczne aspekty turystyki, Instytut Geografii i Gospodarki Przestrzennej, Uniwersytet Jagielloński, Kraków, s. 85-97.

KRZESIWO K., 2014, Rozwój i funkcjonowanie stacji narciarskich w polskich Karpatach, Instytut Geografii i Gospodarki Przestrzennej, Uniwersytet Jagielloński, Kraków.

KUREK W., 2004, Turystyka na obszarach górskich Europy, Instytut Geografii i Gospodarki Przestrzennej, Uniwersytet Jagielloński, Kraków.

LINDBERG K., ANDERSSON T.D., DELLAERT B.G.C., 2001, Tourism development: Assessing social gains and losses, "Annals of Tourism Research", 28, 4, s. 1010-1030.

LUBOWIECKI-VIKUK A.P., PASZYŃSKA-JĘDRYCKA M., 2010, Wspótczesne tendencje w rozwoju form rekreacyjnych i turystycznych, AWF, Poznań.

MADZIKOVÁ A., KLAMÁR R., ROSIČ M., KAŇUK J., 2011, Główne kierunki i problemy rozwoju turystyki narciarskiej w Republice Stowackiej, „Prace Geograficzne”, 125, s. 111-128.

MIKA M., 2009, Ski tourism in the Polish Carpathians - present state and issues of development, „Folia Geographica. Acta Facultatis Studiorum Humanitatis et Naturae Universitatis Presoviensis", 14, s. 198-208.

MIKA M., KRZESIWO K., KRZESIWO P., 2007, Wspótczesne problemy rozwoju ośrodków narciarskich w Polsce - przykład Szczyrku, „Prace Geograficzne”, 117, s. 63-77.

PILAWSKI A., 2002, Skrajne formy aktywności fizycznej, [w:] I. Jędrzejczyk (red.), Rozwój funkcji turystycznej i rekreacyjnej polskich obszarów górskich, Akademia Wychowania Fizycznego w Katowicach, Katowice, s. 88-93.

RUT J., 2002, Turystyka aktywna w Euroregionie Karpackim. Monografia turystyczna, Wyd. Uniwersytetu Rzeszowskiego, Rzeszów. 
SZCZECHOWICZ B., 2006, Funkcjonowanie schronisk turystycznych jako przedsięwzięć komercyjnych, [w:] A. Rapacz (red.), Gospodarka turystyczna w regionie. Przedsiębiorstwo, samorzad, wspótpraca, Wyd. Akademii Ekonomicznej we Wrocławiu, Jelenia Góra, s. 134-142.

SZCZECHOWICZ B., 2014, Poziom i zróżnicowanie cen ustug noclegowych oferowanych przez schroniska górskie na terenie Karpat polskich, stowackich $i$ czeskich, [w:] J. Kantyka (red.), Wellness jako forma kultury fizycznej i turystyki - aspekty zdrowotne i ekonomiczne, Wyd. Akademii Wychowania Fizycznego w Katowicach, Katowice, s. 126-148.

TSUYUZAKI S., 2002, Vegetation development patterns on ski slopes in lowland Hokkaido, northern Japan, "Biological Conservation”, 108,2 , s. 239-246.

TÖGLHOFER CH., 2011, From climate variability to weather risk: The impact of snow conditions on tourism demand in Austrian ski areas, doctoral thesis, University of Graz, Graz.

TUPPEN J., 2002, Recent developments in alpine tourism: A life cycle approach, "Turyzm”, 12, 2, s. 79-93.

WARSZYŃSKA J., 1995, Geografia turystyczna świata, 1, PWN, Warszawa.
WOLAŃSKA T., 1997, Leksykon - sport dla wszystkich, rekreacja ruchowa, AWF, Warszawa.

ZARZYCKI P., STOSIK A., GROBELNY J., 2006, Specyfika funkcjonowania schronisk górskich $w$ świetle zmian otoczenia gospodarczego i dynamiki rozwoju sektora turystyki w Polsce, „Prace Naukowe Akademii Ekonomicznej we Wrocławiu", 1141, s. 303-309.

ŻEMŁA M., 2000, Turystyka kwalifikowana w okresie transformacji w Polsce, [w:] L. Żabiński (red.), Uwarunkowania środowiskowe strategii marketingowych $w$ wybranych sektorach gospodarki, Wyd. Akademii Ekonomicznej w Katowicach, Katowice, s. 199-234.

ŻEMŁA M., 2014, Foreign tourists on hiking trials in Polish mountains, "Geomatics Landmanagement and Landscape", 1, s. 95-106.

ŻEMŁA M., 2015, Reakcje gestorów schronisk na rezerwacje mailowe w różnych językach. Porównanie obiektów w Polsce, Czechach i Stowacji, „Folia Turistica”, 36, s. 125-142.

Artykuł wpłyną: 9 stycznia $2018 \mathrm{r}$. Zaakceptowano do druku:

14 marca $2018 \mathrm{r}$. 